\title{
ECONOMIC COOPERATION OF THE PEOPLE'S REPUBLIC OF CHINA WITH THE INDEPENDENT SOUTH SUDAN
}

\begin{abstract}
The subject of the paper is economic cooperation between the People's Republic of China and South Sudan during the first decade of independence of the African state. The introduction discusses the methodological assumptions of the paper. The first section is devoted to discussing cooperation between countries in the in the oil sector. This is the main area of economic cooperation between states and the oil is the dominant commodity for trade. Its extraction and import by China are systematically hindered due to internal and external conflicts of South Sudan. The second section discusses other aspects of economic cooperation between states. The principles on which economic cooperation is based on are presented. The main areas of interest of Chinese enterprises in South Sudan were outlined. The most important economic agreements concluded between countries were indicated. Development and humanitarian aid provided by China to South Sudan were discussed. The possibilities and requirements necessary to deepen economic cooperation between countries were analyzed.

The purpose of the paper is to discuss, analyze and asses cooperation of the People's Republic of China with independent South Sudan. The main research problem is contained in the question of how economic relations between countries are shaped and what conditions have the greatest impact on them. The main research hypothesis is that economic relations between China and South Sudan are characterized by clear asymmetry and focus on the oil sector. They are above all conditioned by a large difference in the economic potential of states and their roles in the global economic system. The possibility of strengthening and developing economic cooperation mostly depends on the stability of South Sudan.
\end{abstract}

Keywords: People's Republic of China, South Sudan, economic cooperation, crude oil.

\section{INTRODUCTION}

The People's Republic of China (PRC) initiated friendly economic cooperation with southern Sudan as early as 1970 by sending teams of medics and agriculture experts. This cooperation adopted a formal framework in 2005 with the signing of the Comprehensive Peace Agreement between the parties to the civil war in Sudan and the creation of the Autonomous Government of South Sudan (Embassy of the People's Republic of China in South Sudan). On July 9, 2011, South Sudan declared independence, which was confirmed

\footnotetext{
${ }^{1}$ Łukasz Jureńczyk, DSc, PhD, Associate Prof., Head of the Department of Security Policy, Faculty of Political Sciences and Administration, Kazimierz Wielki University in Bydgoszcz, J. Poniatowskiego 12 St., 85-001 Bydgoszcz; e-mail: lukaszjurenczyk@ukw.edu.pl. ORCID: 0000$-0003-1149-925 X$
} 
by the PRC on the same day. This event resulted in the full empowerment of South Sudan in its relations with China.

The purpose of the paper is to discuss, analyze and asses economic relations between the People's Republic of China and independent South Sudan. The main research problem is contained in the question of how economic relations between countries are shaped and what conditions have the greatest impact on them. The guiding research hypothesis is that economic relations between China and South Sudan are characterized by clear asymmetry and focus on the oil sector. They are above all conditioned by a large difference in the economic potential of states and their roles in the global economic system. The possibility of strengthening and developing these relations in sectors other than oil depends in turn on stabilizing the security in South Sudan.

So far, South Sudan has not played a significant role in China's economic policy, but this may change in the long run. This is primarily due to the fact that the country possesses significant deposits of natural resources, including primarily crude oil. Chinese enterprises are also interested in other economic sectors, mainly infrastructure. In turn, for South Sudan, the PRC is a strategic and key economic partner. First of all, South Sudan depends on revenues from oil exports to the Middle Kingdom. In addition, it can benefit from both financial and development assistance from China. The possibility of modeling on the methods of economic transformation of a powerful partner is also of great importance. Among other things, it can use the PRC's experience in poverty alleviation, acquiring modern technologies or boosting foreign investment (Xinhua, yan, 2019). The rapidly developing economic cooperation of the PRC with South Sudan in the first years of its statehood allowed the young African state to record impressive economic growth. However, it was slowed down by the escalating civil war, which resulted in the suspension of most Chinese investments and development projects in South Sudan.

\section{CRUDE OIL PRODUCTION}

The first investments of Chinese oil companies in southern Sudan have been implemented since 1995. In 1996, the Government of China (GOC) granted Sudan the first subsidized loan for oil production with China National Offshore Oil Corporation (CNOOC) (Zhao, 2017). In the late 1990s, the internal conflict between the northern and southern parts of the country intensified. As a result, Western countries imposed economic sanctions on Sudan and withdrew most companies from its territory, expecting the same from Chinese enterprises (Lanteigne, 2016). However, these have not ceased extraction of oil from deposits located in both parts of the country (Gaudreau, 2016). In 2005, the share of Sudanese crude oil in total Chinese oil imports exceeded 5\%. In 2006, China imported 47\% of crude oil extracted in Sudan. In 2007, China accounted for $64 \%$ of all Sudan trade (Lanteigne, 2016). However, the value of China's investments in the Sudanese oil mining sector dropped successively from USD 1.5 billion in 2000-2005 to USD 533 million in 2006-2011. As a result of the outbreak of the conflict between Sudan and South Sudan, in 2012-2014 Chinese companies did not make any investments in the oil sector in any of the Sudanese countries (Johanson, 2016).

After the splitting of Sudan into two countries in July 2011, the Chinese authorities immediately recognized the subjectivity of South Sudan. They wanted to establish political and economic relations with the new state as soon as possible. This was in line with the expectations of South Sudan, which was financially dependent on oil exports to China and 
counted on development support from the world economic power. After the division of the country, China's dominant position on the Sudan oil market translated into a dominant position on the South Sudan oil market. Most Western oil companies did not dare to enter it because of internal and external conflicts and deep corruption of the state. Initially, this did not discourage Chinese state-owned oil companies that had previously carried out high-risk investments in destabilized and highly corrupt countries (Bodetti, 2019). Especially in the period between 2011 and 2013, i.e. after the emergence of South Sudan and before the outbreak of the civil war in that country, Chinese companies saw it as a place worthy of economic involvement. Therefore, they continued to implement previously initiated investments in the oil sector, which resulted in an increase in the number of Chinese working and living in South Sudan (Ali, 2018).

Beijing was motivated to develop economic relations with Juba, but without damage to traditionally friendly relations with Khartoum. The Republic of Sudan was an important supplier of crude oil to China and in the exemplary 2014 its share in total Chinese crude oil imports was about 2\% (Wu, Zhang, 2017). Nevertheless, the oil potential of South Sudan was even more impressive because about $75 \%$ of Sudan's oil fields were located on its territory. In January 2014, reserves of approximately 3.5 billion barrels of oil worth USD 38 billion were confirmed in South Sudan (Hodzi, 2017). Although the new state became the third largest holder of oil reserves in Sub-Saharan Africa, after Nigeria and Angola, it was dependent on the Sudan transmission network. At the beginning of 2012, the share of crude oil from South Sudan in total Chinese oil imports was only about 1\% (Regler, 2016).

After the independence of South Sudan, the GOC confirmed that it will respect oil contracts concluded with the Sudan government regarding oil fields of the new state (China Grants...). Chinese companies, however, had to negotiate with the government in Juba to adapt their contracts to the new political, social and economic reality. While the financial conditions of the contracts were, in principle, maintained, it was necessary to regulate previously neglected issues regarding employment, and social and environmental conditions. This was to reduce the dissatisfaction of local communities and stop their attacks (Attree, 2012). In addition, Juba tried to secure itself against the consequences of downtime in oil production due to political factors, including the escalating conflict with Khartoum (International Crisis Group, 2012). Quick agreement was in the interest of both parties, as Chinese companies control most of South Sudan's oil reserves. China National Petroleum Corporation (CNPC) holds $41 \%$ of shares in the largest South Sudanese oil consortia, i.e. Dar Petroleum Operating Company (DPOC) and the Greater Nile Petroleum Operating Company (GNPOC). In addition, another Chinese mining company - Sinopec - holds a 6\% stake in DPOC. (Hodzi, 2017). Over the first decade of South Sudan's existence, invariably around $98 \%$ of government revenues came from oil fields (Nyabiage, 2019). At that time, almost all of South Sudan's oil exports went to China (Eberling, 2017).

Shortly after independence of South Sudan, tensions with neighboring Sudan increased due to the shape of the border and access to the oil transmission network. The escalating conflict put Beijing in a difficult situation and forced him to implement a skilful policy of balancing between states (Lanteigne, 2016). In the first years of South Sudan, there was distrust between Juba and Beijing, which also affected Chinese oil companies. This resulted from Juba's unwillingness to traditionally close relations between Beijing and Khartoum. The escalating conflict over oil transmission between South Sudan and Sudan led to the expulsion in February 2012 of Liu Yingcai, president of the Chinese-Malaysian oil company Petrodar, which is part of the CNPC group. In addition, the government of South 
Sudan investigated the participation of GNPOP in triggering the interstate crisis and even threatened to withdraw from contracts with this consortium (Ali, 2018).

In January 2012, South Sudan suspended oil exports for fourteen months and thus lost its source of income. The main reason was the inability to agree with a northern neighbor on charges for the transfer of oil by Sudanese pipelines to the Port of Sudan on the Red Sea (Zweig, 2016). At the end of March 2012, border fighting broke out over the oil fields located there. Both Juba and Khartoum expected Beijing to take on the role of conciliator. Although China got involved in these activities, in both Sudanese countries there remained a dissatisfaction as to the specifics and scale of Beijing's help in resolving the conflict (International Crisis Group, 2012). China wanted a quick end to the conflict, but with impartiality towards its participants. Finally, in March 2013, the states withdrew their armed forces from the border area, and in April South Sudan resumed oil extraction and transit through Sudan. The economy of South Sudan has survived this difficult time mainly thanks to loans from China and other countries (Nield, 2013).

The conflict between Sudanese countries has forced China to consider alternative routes for oil transport from South Sudan (Johanson, 2016). Two proposals have become of particular interest. The first concerns the construction of a pipeline from Juba to the port city of Lamu in Kenya. The second involves the construction of a pipeline through Ethiopia to the port in Djibouti, which could cost approximately USD 4 billion (Eberling, 2017). Preliminary agreements regarding the feasibility of building both of these pipelines were concluded in 2012 (Djama, 2012). Later, both projects were discussed at a number of meetings, including the East Africa Oil and Gas Summit (EAOGS) in Nairobi in October 2013 (Shaw, 2016). Implementation of projects, however, prevented the outbreak of civil war in South Sudan on December 15, 2013 between the Dinka and Neur tribes.

As a result of the outbreak of the internal conflict in December 2013, CNPC was forced to temporarily close key oil fields located in the states of Unity and Upper Nile because they were in rebel controlled territory. At the same time, CNPC evacuated about $97 \%$ of Chinese staff to Juba. It was a good decision because oil fields, like for example the Adar Yale oil field in the Upper Nile, were attacked many times. It is worth noting, however, that about $90 \%$ of the workers employed by CNPC in the South Sudan oil fields are local people (Wenting, 2019). At the beginning of the conflict, oil production in South Sudan fell by $20 \%$, and as a result of increased fighting and a dramatic drop in oil prices in the world (from USD 110 in July 2014 to USD 35 in January 2016 per barrel) in 2014 and 2015 production was abot $40 \%$ lower. For this reason, South Sudan's revenues dropped from USD 7.4 billion in 2011 to USD 4.2 billion in 2016. The civil war in South Sudan also negatively affected the profits of Chinese oil companies operating on this market (Hodzi, 2017).

In July 2018, a peace agreement was concluded between the leaders of political parties representing conflicted tribes. As a result, China has again intensified its efforts to strengthen its position in the South Sudan oil market. CNPC won the competition to extract hydrocarbons from deposits located in the center of the country, beating companies from France and Kuwait. In August 2018, the Chinese oil company concluded an agreement in this regard with the Ministry of Petroleum and Mining of South Sudan (MPM) (Bodetti, 2019). Protests of local communities against environmental degradation stood on the way to the implementation of Chinese enterprises' investments in the oil sector. In the northern region of the country where the main oil production base is located, children with body deformities began to be born. Therefore, at the beginning of 2020, the authorities in Juba 
decided to carry out research and expertise to determine the extent of the contaminated area in the vicinity of oil fields (Xinhua, 2020).

During the civil war, the level of oil imports from South Sudan to China fluctuated due to periodically increasing political violence and ethnic conflicts as well as international factors (Hess, Aidoo). After signing the peace agreement, mining began to stabilize, although it was not certain that the parties would comply with the ceasefire. Armed incidents continued to occur, and in some of them Chinese citizens were also killed. On October 19, 2018, fourteen Chinese employees of a local oil company were killed during clashes between Dinka and Nuer fighters in Juba (Jatmika, 2018). According to the MPM, in early 2019, South Sudan produced 170,000 barrels of oil a day. At that time, the share of South Sudanese crude oil in Chinese oil imports consistently fluctuated around 1\% (Okech, 2019). In the first half of 2020, the legitimacy of oil imports from South Sudan was called into question because of the coronawirus pandemic. The price of oil has dropped dramatically, and significant production surpluses have appeared around the world. Under these circumstances, the reduction of production may take place first in fragile states like South Sudan.

\section{OTHER AREAS OF ECONOMIC COOPERATION}

In addition to crude oil, South Sudan also has large deposits of other natural resources, including gold, silver, copper, aluminum and limestone. So far, they are not exploited, mainly due to persistent instability in the country (Eberling, 2017). Potentially Chinese companies are interested in mining them. Chinese enterprises are also interested in other sectors of the economy, mainly in construction. There is a lack of basic infrastructure in South Sudan, including roads, bridges, power plants, electricity grids, dams, water treatment facilities, irrigation systems, schools, hospitals, municipal buildings, telecommunication networks, oil infrastructure etc. (International Crisis Group, 2012).

During the visit to Juba in August 2011, Chinese Foreign Minister Yang Jiechi spoke in favor of continuing the development of "friendly cooperation" between the PRC and South Sudan. He emphasized that countries should, above all, strengthen cooperation in the oil, mining, agriculture and infrastructure sectors. He also made a promise to provide development support for South Sudan and to take multifaceted actions to improve the standard of living of its citizens. In April 2012, President Salva Kiir paid a visit to China, during which he held a series of talks on strengthening economic cooperation between states. He encouraged Chinese state authorities and Chinese companies to invest in South Sudan and asked for financial support (China Grants...). During the visit, the GOC granted South Sudan a credit line on preferential terms for USD 8 billion. It also offered the participation of Chinese enterprises in the construction of South Sudan infrastructure (Eberling, 2017).

The PRC and South Sudan have signed a number of bilateral economic agreements, some of which date back to the pre-independence period of the African partner. The most notable includes: Memorandum of Understanding between the Southern Sudanese Ministry of Water Resources and Irrigation and China Construction and Machinery Company for Future Investments (2006), Trade, Economic and Technical Agreement (November 22, 2011) and Agreement on Economic and Technical Cooperation (April 24, 2012). It is also worth mentioning that in November 2011, South Sudan and China established the Bilateral Joint Economic and Trade Committee (Eberling, 2017). In December 2014, about 140 
companies from China were registered in South Sudan. Most of them were active in the oil and infrastructure sectors (Eberling, 2017). However, many of them were suspended until the situation in the country stabilized.

Western countries providing development assistance to third world countries expect them to meet a number of criteria related to the rule of law, human rights and financial accountability. China, in turn, offers support without such preconditions It grant loans to even the most corrupt governments in the world that commonly violate human rights, without requiring political and economic reforms. This approach is largely due to attachment to the principle of non-interference in internal affairs (Gaudreau, 2016). At the same time, it is the result of a pragmatic approach aimed at expanding economic influence in countries from which Western companies are withdrawing. Directing development aid to South Sudan, the PRC wants to establish friendly relations with it and stabilize the situation in the country and the region. After the end of the internal conflict in South Sudan, China will have a very good starting position for the implementation of large investments, mainly in oil and infrastructure sectors. The PRC will be able to implement the so-called "Angola Model", which bases on the principles of South - South Cooperation. This model is to lead to a win-win solution in cooperation between developing partners. The „Angola Model" primarily consists in granting low-interest loans to states which are more reliant on commodities, such as fossil fuels or mineral resources, as collateral (Lanteigne, 2016). The developing countries guarantee the supply of raw materials, mainly crude oil, to Chinese companies. These, in turn, take part in the implementation of development projects in these countries (Hess and Aidoo, 2015).

Although China's investment in the Sudanese oil industry has been stalled in 2012-2014, China's development aid has increased significantly. For only these two years, China has declared USD 3.2 billion in grants, loans and other forms of support. This was a significant increase, because for the previous six years it was USD 5.2 billion. Of the 46 development projects that China implemented in the Sudanese countries in 2012-2014, 21 went to South Sudan and 25 to Sudan. However, the difference in the value of these projects was drastic, because those implemented in South Sudan cost USD 243 million, which accounted for $7.8 \%$ of the total, and the rest, i.e. almost USD 3 billion, was allocated to projects in Sudan (Johanson, 2016).

Within the limited budget, Chinese authorities and corporations have concluded with South Sudan authorities a number of agreements on development projects and financial support in the areas of agriculture, construction, electricity production, water resources, communication, social infrastructure, transport, storage base, mining, education, management and civil society, and crisis response. On October 24, 2011, the GOC provided South Sudan with a subsidy of US 31.5 million for Chinese enterprises to implement multisectoral development projects in the areas of agriculture, education, health and water resources. During the ceremony, the Chinese ambassador in Juba Li Zhiguo announced the identification of further needs and the preparation of further development projects. At the same time, a significant number of radio stations were handed over to South Sudan to promote media development and Chinese broadcasts (China Grants...).

Other important manifestations of China's aid to South Sudan include: in 2011, a USD 158 million preferential loan from the Export-Import Bank of China (Exim Bank) for China Harbor Engineering Company to develope Jub International Airport; in 2012, a USD 200 million loan from Exim Bank to South Sudan's Commerce Ministry; in 2012, a USD 1.42 billion loan from the Bank of China for China Gezhouba Group for the construction of the 
Biden Hydropower Station; in 2012, an agreement for a borehole drilling project; in 2012, donation of desktop computers and laser printers to the ruling party - the Sudan People's Liberation Movement (SPLM); in 2012, an agreement on agricultural cooperation and rice planting; in 2013, construction of the Disarmament Training Center; in 2013, training for medics and diplomats; in 2014, material aid worth USD 24 million In mid-December 2013, however, the implementation of development projects was suspended for several years as a result of the civil war in South Sudan (Eberling, 2017).

China also supported South Sudan in the areas of health care and humanitarian aid. Chinese medical groups have been operating in clinical hospitals in Juba, Wau and Malakal since 1970. After the declaration of independence by South Sudan in 2011, another medical group of doctors from the Chinese province of Anhui came to the clinical hospital in Juba. Chinese medics in South Sudan clinical hospitals deal with both providing medical assistance and training local staff. They also help to restore and use the medical equipment. The most important project was the joint construction of a hospital in the city of Bentiu for which in 2011 China provided a grant of USD 760 thousand. China has also modernized the Kiir Mayardit women's hospital in Rumbek and trained its staff. In addition, the Chinese government has donated to clinical hospitals in Juba and Wau (Gikiri, 2017). In 2012, China and South Sudan signed a Memorandum of Understanding regarding healthcare and water procurement. In 2013, the parties signed an agreement on the transfer of anti-malaria drugs (Eberling, 2017). In 2019, China sent medical and technical specialists to assist in equipping the Kiir Mayardit Hospital in Rumbek (Yinglun, 2019).

The United Nations Food and Agriculture Organization (FAO) and the World Food Program (WFP) qualify South Sudan as one of the countries most affected by the humanitarian crisis. According to them, about 3.9 million people have limited access to food, and about 100,000 people suffer from hunger (Munene, 2019). Humanitarian aid from the PRC to South Sudan is mainly channeled through the Chinese Red Cross (Gikiri, 2017). For example, in 2012, China provided USD 1.05 million in Emergecy Food Relief, and in 2013, USD 50 thousand for flood relief. In 2014, it donated USD 3 million for humanitarian aid and USD 1.6 million to build a shelter for displaced persons (Eberling, 2017). Chinese companies operating in South Sudan also provide humanitarian aid. For example, CNPC helped build civil protection camps, where thousands of people found shelter (Wenting, 2019). A significant problem was the temporary blockade of humanitarian access to some areas of the Unity, Upper Nile and Western Ecuatoria (Ali, 2018). In 2019, Chinese enterprises undertook to drill 47 wells in search of water. According to Hua Ning - the Chinese ambassador in Juba, this is expected to give access to drinking water for several million inhabitants of South Sudan (Munene, 2019). In December 2019, due to the flood that hit South Sudan, China provided it with USD 500 thousand humanitarian assistance and USD 1.5 million food relief (Yinglun, 2019).

During the war between Sudan and South Sudan and the subsequent civil war in South Sudan, the PRC had a serious dilemma about how to behave in the United Nations Security Council (UNSC). Western countries have repeatedly pressed China to suspend economic cooperation with these countries. In May 2012, China supported UNSC Resolution 2046, which threatend to impose sanctions on Sudan and South Sudan (United Nationas Security Council, 2012). At the same time, however, it prevented Western states from actually imposing sanctions, claiming that they would harm the peace process (Hodzi, 2017). During the civil war, the United States and other Western countries imposed economic sanctions on political and military leaders of South Sudan. The PRC, however, did not decide on 
similar activities (Nyabiage, 2019), but also did not put veto in the UNSC to block them. Anyway, China had to make some concessions on the supply of weapons so as not to be accused of contributing to the escalation of the conflict. In June 2014, China North Industries Group Corporation Limited (NORINCO) was to realize the first supply of arms to South Sudan worth USD 38 million. Due to pressure of the international community, the transaction has been at least partially suspended (Hodzi, 2017). Officially, the total value of arms supplied by the PRC to South Sudan was only USD 22 million. Subsequent deliveries, if carried out, were secret (Eberling, 2017).

After the conclusion of the peace agreement in 2018, China decided to return to the implementation of investment and development projects. In February 2019, Exim Bank concluded a preliminary agreement with the government of South Sudan for the construction of highways, which is to be the largest development project in South Sudan. To finance the project, South Sudan increased the volume of crude oil supplied to Exim Bank from 10,000 to 30,000 barrels per day (Okech, 2019). At the end of March 2019, the South Sudanese government concluded a multi-billion dollar agreement with the Chinese company Shandong Hi-Speed Group Co., Ltd (SDHS) regarding the construction of highways and main roads from Juba to remote regions of the country. The first stage will involve the construction of a section of the highway from Juba to Rumbek in the center of the country, about $400 \mathrm{~km}$ long. President Kiir, who was present at the signing of the agreement, ensured that further highway sections will be contracted soon (Liangyu, 2019). Other Chinese enterprises, including Sinohydro Corporation, are also to participate in the construction of highways and roads. This company is also to build in South Sudan a hydroelectric power plant. China Harbor Engineering Corporation, in turn, has won a contract to renovate the international airport in Juba worth USD 1.6 billion, and ZTE is building a telecommunications network for USD 200 million. Chinese enterprises are also winning smaller contracts for the construction and renovation of other infrastructure elements, including houses, bridges and hospitals (Hodzi, 2017).

Trade between China and South Sudan has also started to stabilize in recent years. In 2019, China imported USD 1.51 billion worth of goods from South Sudan, and exported USD 122.6 million worth of products. As in previous years, crude oil and its derivatives accounted for over $99 \%$ of China's imports. Sudan, in turn, mainly imported electronic devices and mechanical parts (Bilateral trade...). Due to the dominance of crude oil in bilateral trade, a large disparity in trade balance between countries persists.

\section{CONCLUSION}

Due to the large asymmetry of economic potentials and roles in the global economic system, South Sudan should form expectations for the PRC in a balanced and realistic way. Juba must also take into account that Beijing may reject many of the proposals and should not therefore cool relations between states. China, in turn, by pursuing a long-term economic policy towards South Sudan, wants to create a positive climate in bilateral relations (Wani, 2018). Potentially, after stabilizing the security, South Sudan may become a much more important supplier of energy resources to the Middle Kingdom than it is today. In addition, it can also become a place of lucrative investments, including in the oil and infrastructure sectors. For this reason, China should be sensitive to the development needs of South Sudan and treat it subjectively so that it does not feel like a province of Sudan. 
The PRC can offer South Sudan not only capital and equipment, but also know-how and its own experience of economic transformation. South Sudan, in turn, wants to reform the economy, is open to business and is actively looking for foreign investment. Although historically South Sudan is associated with Western countries, its authorities do not give them priority to cooperation. The enormity and urgency of needs means that they are ready to cooperate economically with anyone who offers favorable conditions. China is attached to the idea of cooperation between developing countries as part of the "South-South" concept, seeing itself as the leader of these countries. In addition, it does not set the political preconditions for cooperation, which is seen as an asset due to the complex situation in South Sudan. However, South Sudan should not strengthen economic relations with China at the expense of correct relations with the West. In addition, it must ensure that economic development contributes to strengthening security and stability in the country (International Crisis Group, 2012). Profits from the sale of crude oil to China should therefore be directed towards the implementation of infrastructure investments, including in social infrastructure. These projects are ready to be implemented by enterprises from China, but the condition is to stabilize the situation in the country. In turn, improving the well-being of citizens can accelerate the peace process, help national reconciliation and increase public support for China's economic involvement in South Sudan.

With the increasing involvement of Chinese enterprises in destabilized and armed conflict areas, the demand for new methods of investment risk analysis is increasing in China. This applies to both the analysis of the specifics and dynamics of the conflict itself, the security of installations and personnel, as well as the security of financial settlements. Because in recent years there was a very high investment risk in the unstable South Sudan, the scale of loans, capital investments and development projects was relatively small compared to more stable Chinese partners from Africa. Nevertheless, there was no complete withdrawal, as was the case with many Western states and companies. For this reason, when peace is managed in South Sudan, China will have a privileged starting position. Recently signed infrastructure contracts show that both Chinese companies and the government of South Sudan are ready for such cooperation. So there may be practical implementation in South Sudan of the so-called "Angola Model". On the other hand, if the peace agreement is not maintained and the fighting breaks out again, the cost of PRC's economic involvement in this country will increase. This could eventually lead to a loss of patience and reduce China's economic involvement in South Sudan. Therefore, it is in the interest of the partners to restore security in the country. An additional problem is currently the consequences of the coronavirus pandemic in the global economy and in the global energy market.

\section{REFERENCES}

Ali, M. A. (2018). China and The Conflict in South Sudan: Security and Engagement. „Journal of Economic, Administrative and Legal Sciences" Issue (2), Vol. 2.

Attree, L. (2012). China and conflict-affected states. Between principle and pragmatism. London: Saferworld.

Bilateral trade between China and South Sudan in 2019. (2019). Acces on the internet: https://www.trademap.org/Bilateral.aspx?nvpm=1\%7c156\%7c\%7c728\%7c\%7cTOTAL\% $7 \mathrm{c} \% 7 \mathrm{c} \% 7 \mathrm{c} 2 \% 7 \mathrm{c} 1 \% 7 \mathrm{c} 1 \% 7 \mathrm{c} 1 \% 7 \mathrm{c} 1 \% 7 \mathrm{c} \% 7 \mathrm{c} 1 \% 7 \mathrm{c} 1 \% 7 \mathrm{c}$ 
Bodetti, A. (2019). How China Came to Dominate South Sudan's Oil. „The Diplomat”. 11 February. Access on the internet: https://thediplomat.com/2019/02/how-china-came-todominate-south-sudans-oil/

China grants South Sudan \$31.5m for development projects. (2011). 25 October. https://www.sudantribune.com/spip.php?iframe\&page=imprimable\&id_article $=40523$

Djama, A. D. (2012). South Sudan signed an oil pipeline deal with Ethiopia and Djibouti. 3 October. Access on the internet: http://www.unfalumni.org/south-sudan-signed-an-oilpipeline-deal-with-ethiopia-and-djibouti/

Eberling, G. G. (2017). China's Bilateral Relations with Its Principal Oil Suppliers. London: Lexington Books.

Embassy of the People's Republic of China in South Sudan. (2012). Sino-South Sudan Political exchanges. 23 November. Access on the internet: http://ss.chineseembassy.org/eng/ sbgx/zjjw/

Gaudreau, M. (2016). Plurality in China's South-South Cooperation: The Case of Rice Projects in Mali [w:] Cao H., Paltiel J., eds., Facing China as a New Global Superpower Domestic and International Dynamics from a Multidisciplinary Angle. Singapore: Springer.

Gikiri, S. N. (2017). Chinese Health Assistance (CHA) in East Africa. „IOSR Journal Of Humanities And Social Science" Issue 1, Vol. 22, Ver. 5.

Hess, S., Aidoo, R. (2015). Charting the Roots of Anti- Chinese Populism in Africa. New York: Springer.

Hodzi, O. (2017). Strategy of 'Parallels': China in the South Sudanese armed conflict. Paris: Asia Centre. Access on the internet: https://centreasia.eu/en/strategy-of-parallels-china-inthe-south-sudanese-armed-conflict-2/

International Crisis Group. (2012). China's New Courtship in South Sudan. Africa Report $N^{\circ} 186.4$ April. Access on the internet: https://d2071andvip0wj.cloudfront.net/186-china-snew-courtship-in-south-sudan.pdf.

Jatmika, A. (2018). 14 Chinese Workers Killed in South Sudan. 19 October. Access on the internet: https://en.tempo.co/read/539251/14-chinese-workers-killed-in-south-sudan

Johanson, D. (2016). China's Soft Power in Sudan: Increasing Activity but How Effective? [w:] Zhang, X., Wasserman, H., Mano, W., eds., China's Media and Soft Power in Africa Promotion and Perceptions. London-New York: Palgrave Macmillan.

Lanteigne, M. (2016). Chinese Foreign Policy. An introduction. Third edition. London-New York: Routledge.

Liangyu. (2019). South Sudan reaches deal with Chinese firm to start construction of major roads. 27 March. Access on the internet: http://www.xinhuanet.com/english/africa/201903/27/c_137925447.htm

Munene, D. (2019). Peaceful resolution required in S. Sudan. „China Daily” 30 September. Access on the internet: https://www.chinadailyhk.com/articles/128/150/110/ 1569824799359.html

Nield, R. (2013). Sudan-South Sudan oil deal has its limits. 17 April. Access on the internet: https://foreignpolicy.com/2013/04/17/sudan-south-sudan-oil-deal-has-its-limits/

Nyabiage, J. (2019). Why China is hoping for a peace dividend in South Sudan. „South China Morning Post" 5 October. Access on the internet: https://www.scmp.com/news/ china/diplomacy/article/3031640/why-china-hoping-peace-dividend-south-sudan

Okech, F. (2019). China Gets a Sixth of South Sudan Oil Output to Build Highways. 5 April. Access on the internet: https://www.bloomberg.com/news/articles/2019-04-05/china-getsa-sixth-of-south-sudan-oil-output-to-build-highways 
Shaw, T. M. (2016). African Agency Post-2015: The Roles of Regional Powers and Developmental States in Regional Integration [w:] Levine, D.H., Nagar D., ed., Region-Building in Africa Political and Economic Challenges. Cape Town: Palgrave Macmillan.

South Sudan Trade Balance. (2017). Access on the internet: https://oec.world/en/profile/ country/ssd/

Wani D. C. (2018). China-South Sudan Relations: From Margin to the Spotlight. „Modern Diplomacy” 2 October. Access on the internet: https://moderndiplomacy.eu/2018/10/02/ china-south-sudan-relations-from-margin-to-the-spotlight/

Wenting, M. (2019). Chinese peace: Untold stories on the ground in South Sudan. „China Daily” 6 October. Access on the internet: https://global.chinadaily.com.cn/a/201910/06/ WS5d99566da310cf3e3556ee1b.html

Wu, F., Zhang, H. (2017). Introduction: A rising China and the future of world resources [w:] Wu, F., Zhang, H., eds., China's Global Quest for Resources. Energy, food and water. London-New York: Routledge.

Yinglun, S. (2019). China provides emergency assistance to flood-hit South Sudanese. 4 December. Access on the internet: https://reliefweb.int/report/south-sudan/chinaprovides-emergency-assistance-flood-hit-south-sudanese

Xinhua (2010). South Sudan takes action against oil pollution. 5 February. Access on the internet: http://www.china.org.cn/world/Off_the_Wire/2020-02/05/content_75676510.htm

Xinhua, yan (2019). Ties with China important for South Sudan development: experts. 26 October. Access on the internet: http://www.xinhuanet.com/english/2019-10/26/ c_138505680.htm

Zhao, H. (2017). China's Energy Quest in Southeast Asia: 'Mercantilist Rise' debated [w:] Wu, F., Zhang, H., eds.., China's Global Quest for Resources. Energy, food and water. London-New York: Routledge.

Zweig, D. (2016). Modelling 'resource diplomacy' under hegemony: the triangular nature of Sino-US energy relations [w:] Hao, Y., Zweig, D., eds., Sino-US Energy Triangles. Resource diplomacy under hegemony. London-New York: Routledge.

DOI: $10.7862 /$ rz.2021.hss.03

The text was submitted to the editorial office: April 2020.

The text was accepted for publication: March 2021. 
